University of Nebraska - Lincoln

DigitalCommons@University of Nebraska - Lincoln

\title{
Dying for the Nation: Rite of Passage, Homoeroticism and Martyrdom in the Falangist Narrative during the Spanish Civil War
}

Iker González-Allende

University of Nebraska-Lincoln, igonzalezallende2@unl.edu 


\title{
Dying for the Nation: Rite of Passage, Homoeroticism and Martyrdom in the Falangist Narrative during the Spanish Civil War
}

\author{
IKER GONZÁLEZ-ALLENDE
}

University of Nebraska-Lincoln

\begin{abstract}
Eugenio o proclamación de la Primavera (1938) by Rafael García Serrano, and Unificación (1937) by Jacinto Miquelarena are two propagandistic works in which the male protagonists most fully embody the core values of Falangist masculinity. The glorification of youth appears clearly in the two texts, along with an emphasis on violence. War becomes the rite of passage for the two male protagonists, who also renounce romantic relationships to devote themselves to the nation. The two main characters find in their fellow comrades a substitute for their families; in this sense, the nation is constructed as a masculine project. The presence of male bonding and affection among the soldiers allows for a homoerotic interpretation that challenges the heteronormative values of military masculinity. When the protagonists die at the end of the works, they are identified with Christ, since their blood becomes part of the national landscape and will produce new heroes.
\end{abstract}

\section{Resumen}

Eugenio o proclamación de la Primavera (1938) de Rafael García Serrano, y Unificación (1937) de Jacinto Miquelarena son dos obras propagandísticas en las que los protagonistas personifican al máximo los valores principales de la masculinidad falangista. En estos dos textos, se glorifica a la juventud, caracterizada por sus impulsos violentos. La lucha armada se convierte en el rito de iniciación a la masculinidad para los dos protagonistas, quienes renuncian al amor para dedicarse por completo a la nación. Los dos protagonistas hallan en sus compañeros un sustituto de sus familias; en este sentido, la nación se construye como un proyecto masculino. La presencia de lazos afectivos entre los soldados posibilita una interpretación homoerótica que desafía los valores heteronormativos de la masculinidad militar. Cuando los protagonistas mueren al final de las obras, se les identifica con Cristo, puesto que su sangre pasa a formar parte del paisaje nacional y creará nuevos héroes. 
All wars are boyish, and are fought by boys.

Herman Melville, 'The March into Virginia'

La mort est le commencement de l'immortalité. Maximilien de Robespierre

The soldier represents the most prominent example of masculinity in service of the nation. Since strength, courage, competitiveness and phallocentrism characterize normative masculinity, wars are usually key opportunities to validate national virility. In fact, as George Mosse explains, wars become an appeal to masculinity (1985: 114). During the Spanish Civil War (1936-1939), the Republicans and the Francoist rebels, the two main political forces, shared a similar construction of masculinity in relation to the nation despite their ideological differences. Using the rhetoric of sacrifice in the name of a collective cause, men of all ages were asked to take up arms in order to defend women, for within military and national ideologies, the female body tends to be a metaphor for the nation. Compared to the Republicans, the Francoist rebels combined to a greater degree those classical values of military masculinity with the notion of a celebratory death, understood as both the climax of a meaningful life and the beginning of a blissful, everlasting existence in heaven.

Despite the numerous studies about the Spanish Civil War, there has not yet been a detailed analysis of the representation of the soldier's masculinity and its connection to the nation. Studies that specifically investigate the Falange - often considered the Spanish version of fascism - have focused mainly on its history, ideological components or the role that women played in the Feminine Section. ${ }^{1}$ The Falange's idealized depiction of masculinity has not received critical attention because this political movement, as in the case of most national ideologies, presented male performance as a natural phenomenon, not as a cultural construction.

This paper analyses the portrayal of the soldier's masculinity within the Falange at a moment of national crisis. I will study two works written during the Spanish Civil War in which the male protagonists most fully embody the core values of Falangist masculinity: Eugenio o proclamación de la Primavera (1938), by Rafael García Serrano, and Unificación (1937), by Jacinto Miquelarena. I will examine the depiction of normative values of military masculinity in these texts, focusing on the following factors: how war becomes a rite of passage into manhood, how camaraderie or fraternity on the front plays an essential role in

1 José Antonio Primo de Rivera wanted to differentiate the Falange from European fascism. To answer those who blamed him for imitating Italy and Germany, he stated in 1934: 'Estos países dieron la vuelta sobre su propia autenticidad, y al hacerlo nosotros también, la autenticidad que encontraremos será la nuestra, no será la de Alemania ni la de Italia' (1945: 33). However, Primo de Rivera received economic help from Mussolini and his political party exhibited many characteristics of the other fascist movements, such as antiliberalism, anti-communism, goal of an empire, emphasis on symbols, positive evaluation of violence, stress on the masculine principle, tendency towards personal leadership, and exaltation of youth, among others (Payne 2003: 84-85). 
creating an imagined community, how the soldier establishes a close relationship with nature and thus becomes part of the national landscape, and how death is considered martyrdom - the ultimate sacrifice for the nation. Additionally, I will explain how these works sometimes allude to aspects - mostly the presence of homoeroticism among soldiers - that contradict the model heterosexuality defended by military and national ideologies.

García Serrano and Miquelarena were two of the main Spanish Falangist writers of the first half of the twentieth century. García Serrano (b. Pamplona, 1917; d. Madrid, 1988) joined the Falange party at a young age and battled in street skirmishes against liberal students just before the Spanish Civil War broke out. During this war, he fought as a soldier but, after an injury, was forced to leave the front. This experience had a profound impact on his life, as is evidenced by his literary production, which is almost exclusively about the Spanish Civil War. ${ }^{2}$ García Serrano was loyal to the Falange until his death. This dedication led Andrés Trapiello to write that after the war, García Serrano exuded the greatest nostalgia for the Falange (1994: 359).

Jacinto Miquelarena (b. Bilbao, 1891; d. Paris, 1962) belonged to what Julio Rodríguez Puértolas called 'the literary court of Primo de Rivera' - the group of writers who were friends of and collaborated with the founder of the Falange (Rodríguez Puértolas 1986: 106). During the Spanish Civil War, Miquelarena wrote three other books apart from Unificación: El otro mundo (1938), about his experience as a political refugee in the Argentinean embassy of Republican Madrid; Cómo fui ejecutado en Madrid (1937), a collection of essays in opposition to the Republican Government; and Cuentos de humor (1939), several witty short stories without an explicit political ideology. ${ }^{3}$

García Serrano's novel tells the story of a young Falangist college student named Eugenio. Eugenio decides to sacrifice his life to fight communism, liberalism and bourgeois values in street skirmishes that take place in Madrid just before the military uprising of 1936. Thus, although the protagonist is not an actual soldier, his life becomes an armed fight. The other important character is Rafael, who acts as the narrator and witness of Eugenio's deeds. While Eugenio represents the man who fights for the nation's sake, Rafael symbolizes the intellectual and reflective man who is also necessary to write the nation's history. ${ }^{4}$ The editio princeps includes several illustrations that are unsigned, but probably

2 While García Serrano was in hospital, he wrote La fiel infantería (1943), his most famous novel. Other works of his about the Spanish Civil War are Plaza del Castillo (1951) and Diccionario para un macuto (1963). In 1983 he published his memoirs, entitled La gran esperanza.

3 Previously, Miquelarena had written works about his travels: El gusto de Holanda (1929), and Pero ellos no tienen bananas (1930). After the war, he published the novel Don Adolfo el libertino (1940), the collection of essays Un corresponsal en la guerra (1942), and a compilation of short humorous sentences, El lenguaje del amor y las mil y una frases peregrinas (1951).

4 García Serrano incorporated many autobiographical elements into the character of Rafael. As I analysed in a previous essay, not only are their names the same but the author also experienced the violent university environment prior to the war (González-Allende 2004: 83). 
were created by Andalusian José Caballero, one of the most prominent Spanish Surrealist artists. ${ }^{5}$

Unificación is a short dialogue that Jacinto Miquelarena published under the pseudonym 'El Fugitivo'. ${ }^{6}$ The author chose this fictitious name because he concealed himself in Republican Madrid during the war and had to escape from the enemy on multiple occasions. The booklet contains several illustrations by Teodoro Delgado, an important member of the Francoist Propaganda Delegation. ${ }^{7}$ In this work, Miquelarena symbolizes the decree of unification of 19 April 1937 - when Franco decided to unify the Carlists and Falangists in a single political party, FET y de las JONS (Payne 1961: 168-69). ${ }^{8}$ As in Eugenio, the protagonists are also two males, but both of them fight on the front. The two soldiers represent two different archetypes, as neither of them is given a proper name: one is a middle-aged Requeté - the term referring to a Carlist soldier - and a family man, while the other is a young Falangist with no family. Despite their differences, they are both courageous and symbolize the nation's normative male behaviour.

These two works exemplify what R. W. Connell calls 'hegemonic masculinity', the privileged and most visible form of masculinity in society (2001: 49). During times of war, hegemonic masculinity translates into military masculinity based on characteristics such as physical strength, heterosexuality, phallocentrism, stoicism and heroic achievement (Woodward 2003: 44). Physical strength stands out from all these traits because it has traditionally been associated with virility. According to George Mosse, the masculine ideal based on physical power and a muscular body follows the Greek model and has been used in Europe since the end of the eighteenth century and the genesis of national ideologies (1985: 23). Nationalism tends to connect male vigour with health and courage, both of which are necessary for the nation's future.

The texts by Miquelarena and García Serrano tend to stress the characters'

5 I thank Jordana Mendelson for suggesting Caballero as the artist of these illustrations. During the war, José Caballero worked for the Francoist Propaganda Department, for which he created several covers and illustrations for the magazine Vértice. His friendship with leftist intellectuals before the war, such as Federico García Lorca, with whom he collaborated in the theatre group La Barraca, caused Ernesto Giménez Caballero and other Francoists to become distrustful of him (García-Posada 1998: 20).

6 Miquelarena had published a previous version of this dialogue in the newspaper $A B C$ on 25 July 1937, under the title 'Por España, unidos en la guerra y en la muerte' (Carbajosa 2003: 141). He also published the dialogue with no changes in the last part of his book Cómo fui ejecutado en Madrid (1937), but in this case no illustrations were included.

7 Before the war, Teodoro Delgado had worked in Paris and Buenos Aires, and collaborated with $A B C$ and the magazine Blanco $y$ Negro. In 1937, he created the famous poster 'España fue, es y será inmortal'. Ángel Llorente considers him one of the most important illustrators on the rebel side (1995: 196).

8 Historically, not all Carlists and Falangists approved of the unification. Jordi Canal points out that despite the fact that Carlists were on the winning side of the war, the year 1939 meant the beginning of their defeat (2000: 65). Furthermore, the Carlist and Falangist leaders who opposed the unification, Manuel Fal Conde and Manuel Hedilla, suffered exile and imprisonment, respectively (González Cuevas 2000: 139). 
physical prowess. For instance, Eugenio is described as 'fuerte, sano, valiente' (García Serrano 1938: 20). When he clashes with a young man from the French embassy, he knocks him down easily, after which he faces three other men, who become frightened and flee without fighting. His manly and attractive physique, as well as his heroic destiny, is represented in the expression that Rafael often uses to call him: 'el bien engendrado' (23).

In Unificación, the Requeté is depicted as 'barbudo y fuerte' (Miquelarena 1938a: 2). His full beard symbolizes his maturity and virility. He even so describes himself: 'Mi pecho es fuerte, mi mano es firme' (4). The case of the Falangist differs somewhat because the author presents him almost as a child, which causes the reader to question how strong he can actually be. In fact, there is a contradiction regarding this characterization in Teodoro Delgado's illustrations. On the cover of Unificación, the Falangist's face shows his youth (Fig. 1); he even displays certain feminine traits such as prominent cheekbones, curved eyebrows and long eyelashes. However, the Falangist's femininity on the cover conflicts with his representation in the other images of the book. For instance, in Fig. 2, the Falangist walks next to the Requeté, and although the latter is taller than the former, both have strong and muscular physiques. Their chests are especially well developed, a symbol of national strength. ${ }^{9}$

A strong body is created mostly by means of exercise and sport. National ideologies emphasize the importance of sports because sports are purported to prepare young men physically to fight in wars and foster an atmosphere of national unity. Through sports, future soldiers learn to cooperate with each other, to identify with other members of their team, and to recognize their common bonds (Wakefield 1997: 8). Military organizations also believe that exercise prevents effeminacy and creates manly and pure men. ${ }^{10}$ The Falange knew that sports were very relevant for the construction of the new nation. For this reason, its publication, entitled FE (1933-34), included a sports section called 'Aire libre', which appeared unsigned, but was probably written by Jacinto Miquelarena.

In Eugenio, sports are mentioned on several occasions. The author presents the main character swimming naked in the river during his vacation. Eugenio's nudity does not imply a threat to respectability, since representations of nude male figures were common in Nazism, but their transparent whiteness 'raised them above the personal and sensual' (Mosse 1999: 188). Similarly, Eugenio's swimming scene can be interpreted as his union with both nature and national

9 The ideal of the strong citizen soldier is not exclusive to fascist movements. For example, Mosse finds a similar recurrence of male strength and virility in socialism (1996: 130). In fact, during the Spanish Civil War, both Francoist rebels and Republicans used sculpted, muscular male imagery to represent national power.

10 National ideologies also emphasized the importance of exercise for women. For instance, during the dictatorship, women would work out through the Feminine Section of the Falange, but always with their bodies fully covered. However, according to Francoism, men's sports were the means to create a strong nation, while women's were simply a way to improve their health and their possibilities of reproduction. 

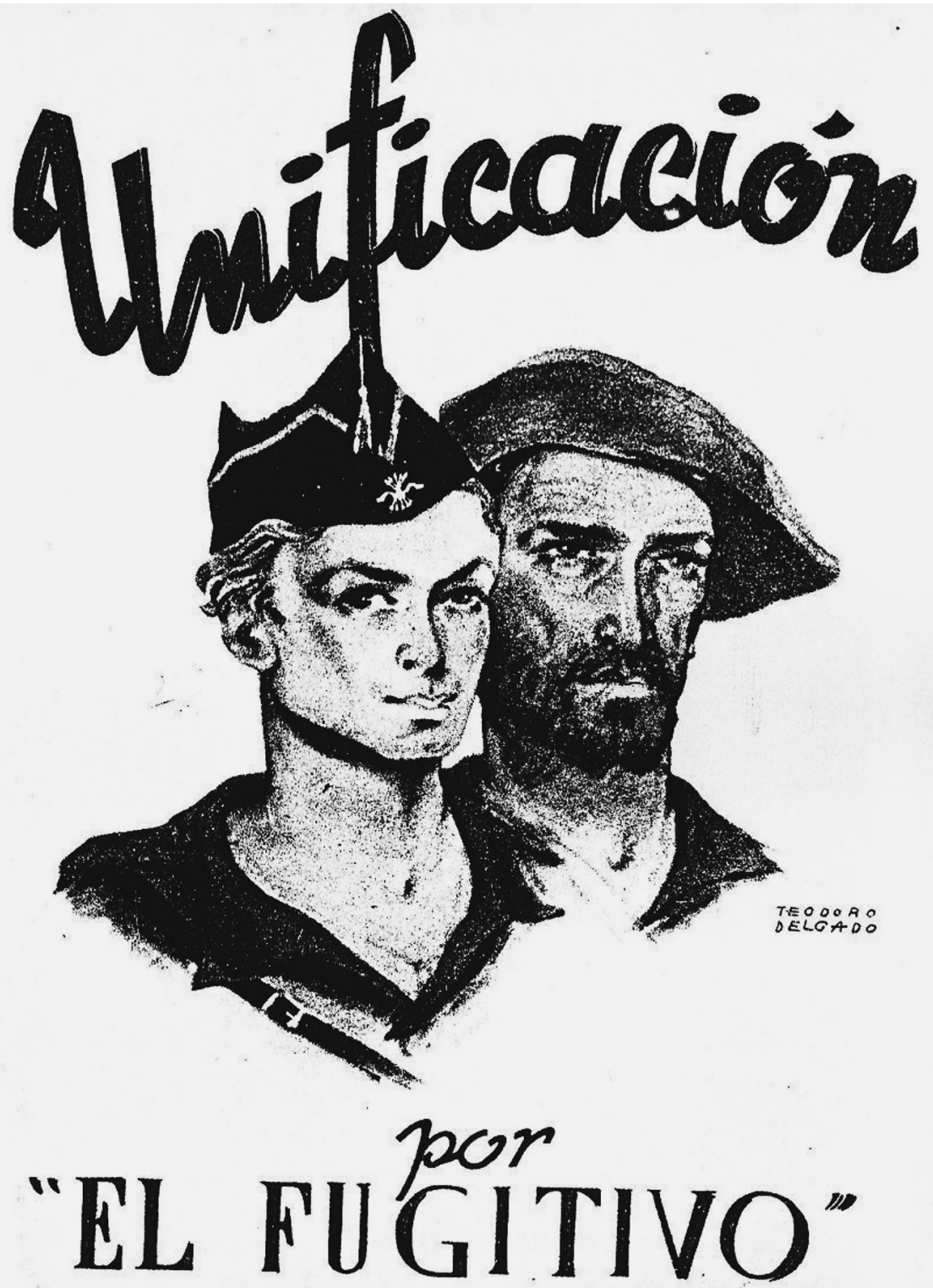

Fig. 1: Cover by Teodoro Delgado for Unificación (1937), by Jacinto Miquelarena ('El Fugitivo').

origins, away from bourgeois and urban modernity. Another sport the main character plays is soccer, in which aggressive behaviour stands as a metaphor for violence during war. The way the narrator describes Eugenio's performance in a soccer match clearly exemplifies the connection between sports and war: ' $Y$ poniéndose en pie entra violentamente a un delantero. Con demasiada violencia. 


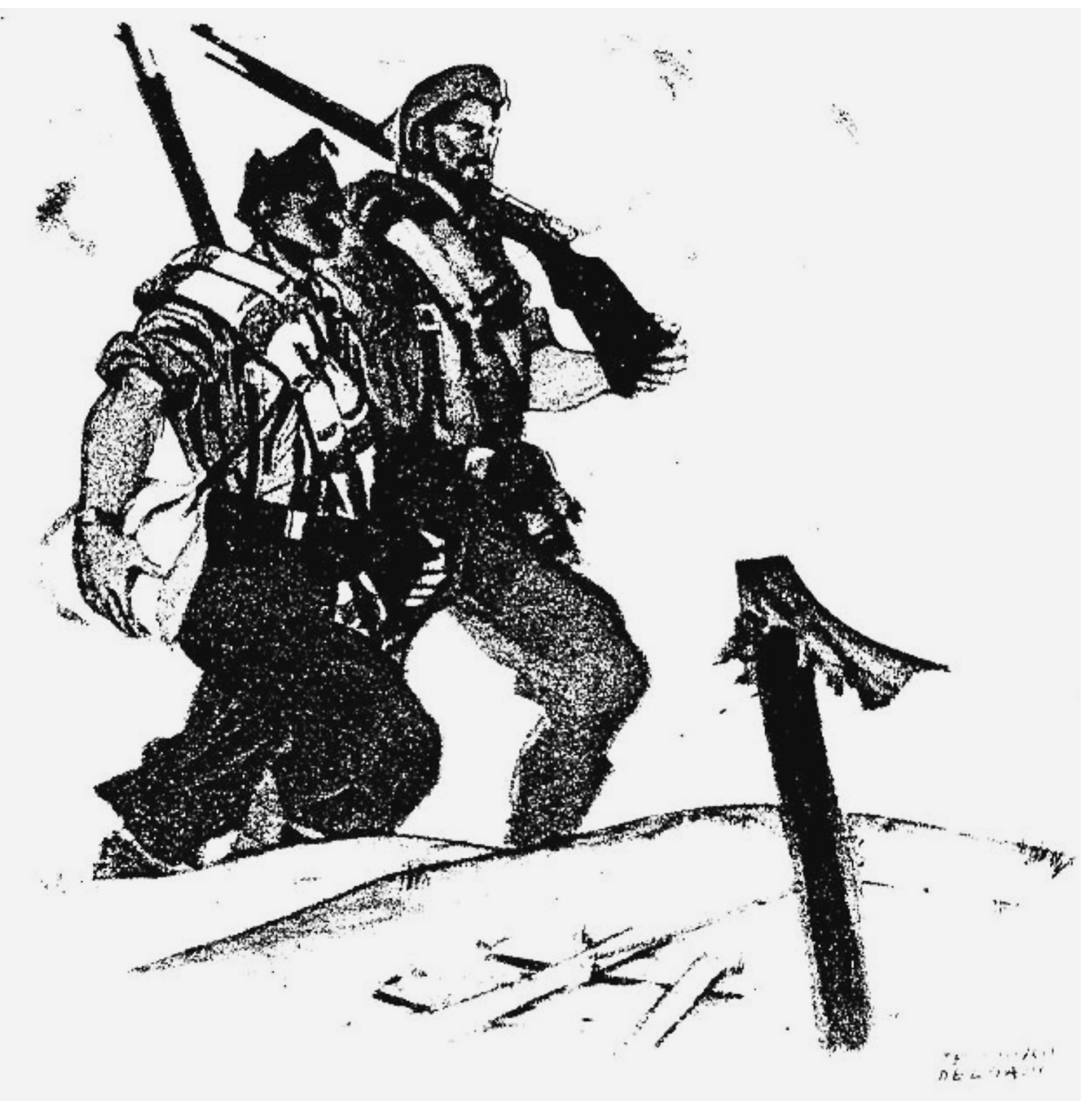

Fig. 2: Illustration by Teodoro Delgado for Unificación (1937), by Jacinto Miquelarena.

Como si esperase ganar el cielo deportivamente' (García Serrano 1938: 89). Soon afterwards, when one of the young Falangists is injured when fighting in the streets, the narrator again relates the fight to sports: 'Si no fuese porque sangra estúpidamente me creería en pleno deporte' (90).

The main characters' physical strength is connected with their youth. In the two works, the Falangist protagonists are very young, which makes their participation in the war more valuable because they are risking a potentially long life. During war, soldiers' youth is a source of pride for the political or national ideologies they represent, since it proves they have spread extensively to citizens of all ages. In addition, youth is an obvious symbol of the nation's prosperity: a nation with young, strong, and courageous male patriots will enjoy a successful future. According to Paul Fussell, wars depend in a great measure on young 
men because they have two traits necessary to fight: stamina and naivety regarding their mortality (1989: 52). The Falange insisted on the ideal of youth more than the Republicans and the other Francoist groups. Young Falangist members enthusiastically embraced the 'romantic' vision of an imperial Spain and the need for a national renovation. This characteristic relates the Falange to other fascist movements. As Mosse points out, 'fascism was a movement of youth' who rebelled against society and found in war their raison d'être (1999: 13). Payne also indicates that one of the main characteristics of fascism was the 'exaltation of youth above all other phases of life, emphasizing the conflict of generations' (2003: 85).

In Eugenio, the narrator portrays the protagonist as a teenager: 'supo batirse - él, adolescente - con rango viril' (García Serrano 1938: 99). At the end of the novel, when he dies, the reader discovers that he had recently turned twenty years old. In fact, Eugenio himself acknowledges that young men are the ones in charge of constructing the nation: 'Ahora estamos en horas adversas: somos la juventud elegida' (69). In his foreword, García Serrano explains that the story is based on experiences of people younger than twenty years old. He also describes the Falangists as young and revolutionary (11). In fact, 60 or 70 per cent of the Falangists in 1936 were below the age of 21 (Payne 1961: 82). The author expressed the same idea in his article 'Descubrimiento de la revolución', published in the newspaper Arriba España in 1938: 'España ha sido y sigue siendo cuestión de jóvenes’ (Díaz-Plaja 1979: 176).

The Falangist of Unificación is described, at the beginning of the work, as 'casi un niño' (Miquelarena 1938a: 2). He also likes to mention his youth and repeats on several occasions: 'Yo soy el más joven camarada de José Antonio' (2). Despite the Falangist's youth, the Requeté emphasizes his bravery before they both die: ‘Adiós, pequeño, eres muy grande!' (11). In this exclamation, the antithesis between 'little' and 'big' shows that a young person who is so courageous deserves the elders' admiration. In contrast to the majority of young men in the Falange, many Carlist soldiers were much older, as is evident in Miquelarena's work. The Requeté is middle-aged, but he says that his 65-year-old father and his 15-year-old son are also fighting on the front (1938a: 6). The presence of three generations of the same family in the war demonstrates how Carlist political values and traditions pass from fathers to sons, a legacy that is not present in Falangist or Republican texts. This patrilineality exemplifies Carlism's overwhelmingly masculine orientation (MacClancy 2000: 27).

In addition to their physical strength and youth, Eugenio and the Falangist share a violent and impulsive disposition. This demeanour speaks to the inherent aggressiveness of certain masculine institutions such as the army (Connell 2000: 215). In the Falange, male violence is such an important part of what defines manliness that it is even equated with beauty; for instance, the narrator describes Eugenio as 'hermoso en su cólera' (García Serrano 1938: 20). In this novel, there are many examples of the fury of the main character. In fact, when Eugenio appears for the first time, the narrator emphasizes this personality trait: 'todo él 
era un haz de nervios tensos, dispuestos al asalto. Por momentos parecía la cólera más intensa en sus ojos' (18). Eugenio himself asserts that instincts should be valued over reflection: 'La táctica es un problema intelectual y el nuestro es golpe de sangre, arriba de corazones. Igual que todo nuestro ideario: corazón’ (48). Falangists rejected suffrage and believed that the only means to achieve their goal of a new Spain was through the use of violence. Eugenio expresses this idea clearly: 'No saben que la civilización se defiende a tiros' (90). The last principle of the Falange regulations highlights the importance of fighting to achieve national revolution: 'Su estilo preferirá lo directo, ardiente y combativo. La vida es milicia y ha de vivirse con espíritu acendrado de servicio y sacrificio' (Doctrina 1939: 15).

Chapter five, entitled 'Pedagogía de la pistola', presents the most direct connection between Falangist violence and masculinity. For José-Carlos Mainer, this chapter constitutes the key text of Spanish fascism (Mainer 2001: 181). Eugenio shoots a man for the first time, an act that signifies his entrance into the realm of masculinity: 'Estábamos conformes en que el magisterio de la pistola era una asignatura más en la ciencia de ser hombre. Hombre’ (García Serrano 1938: 63). The repetition of the word 'hombre' makes the association between masculinity and violent behaviour more obvious still, in addition to adding a lyrical tone to the sentence - a distinctive characteristic of Falangist texts.

In Unificación, the Falangist's violence manifests itself in his impulsive demeanour. For example, when the Requeté volunteers to go in front to protect him, the Falangist answers: ‘ßBah... déjame en paz!’ (Miquelarena 1938a: 8). For him, war is a game, an idea that Gareth Thomas finds in many Falangist novels: 'war is an exhilarating and adventurous experience, in which courting death becomes a game to be played out each day' (Thomas 1990: 69). Furthermore, for young soldiers war becomes a training game that teaches them how to turn into men. Both the Falangist and Eugenio experience combat as an awakening or rebirth into manhood. Eugenio expresses this change as a break with his previous life: 'arrojé por la borda [...] los rastros y reliquias de una vida pasada. Lentamente. Porque ya soy hombre de acción. De choque’ (García Serrano 1938: 62). Numerous studies point out that participation in a war or in the army implies a rite of passage into masculinity; it is the means by which a young man is considered a 'real' man in society (Woodward 2003: 43). Governments are aware that the promise of masculinity is effective to attract young males into the army. In this sense, works such as Eugenio and Unificación played the propagandistic role of convincing young men to fight and die on the front line. In many cultures, masculinity has to be proven and corrected publicly, whereas femininity is considered natural and private. Leo Braudy explains the phenomenon this way: 'Being a man is thus a willful act, celebrated by the tribe, while being a woman is the default or natural state. Male initiation is complex and public, while menarche, even though young girls may also experience it as a wound, usually happens in private, whether there is any subsequent celebration or not' (2003: 19).

Eugenio and the Falangist behave in such an impulsive manner because they cannot bear to be branded publicly as cowards. Their hyper-masculine attitude 
may be explained by their impression that society is observing and judging them. Masculinity requires an audience, especially at times of war, when there are high social expectations regarding appropriate male behaviour. When men accept their role as soldiers and protectors of women and nations, they feel liberated from the anxiety of being considered unmanly (Dawson 1994: 282). For this reason, when Rafael compares himself with Eugenio, he feels ashamed for not fighting actively for the Falange cause.

Men may go to the front line not only to prove their masculinity but also to experience male camaraderie. Within national ideologies, male friendship is essential to the construction of national unity (Mosse 1990: 22). In this sense, Benedict Anderson considers the nation an 'imagined community' that is formed 'as a deep, horizontal comradeship' (Anderson 1991: 7). However, this comradeship includes only males; the nation is always imagined as a fraternity, not as a sorority (Eisenstein 2000: 41). Thus, the nation is constructed as a masculine project. During wartime, the national fraternity becomes stronger because the extreme experiences of suffering that soldiers have to face together - hunger, cold, loneliness, fear and even death - make them grow closer. According to Deborah Harrison, the risk of dying in combat constitutes the circumstance that most intensely unites soldiers and differentiates them from the civil population (2003: 76).

Male bonding is vital in these two texts. In Eugenio, the friendship between the two main characters is very strong. Eugenio acts as a superior officer who teaches Rafael how a real Falangist man must behave. For Rafael, Eugenio represents the type of man he would like to be and, therefore, many of his comments show great admiration towards Eugenio. Male comradeship was essential for the Falange, owing to its militaristic and masculinist nature. This explains why García Serrano dedicates the novel to his fellow soldiers who died in defence of their ideas. The subtitle of the work also illustrates the fraternity and esteem the author felt for the other Falangists: 'Ésta es como la historia del muerto que yo hubiera querido ser' (1938: 5).

In Unificación, camaraderie is exemplified through the friendship between the Falangist and the Requeté. Despite the fact that the Falangist is from Castille and the Requeté from Navarre, both of them are united by the same political cause. Through military service or war, the soldier meets men from other parts of his country, which causes him to feel that he actually belongs to his nation. The difference in age between the two characters makes the Requeté play a pseudopaternal role, although both try to protect each other. When the Falangist is wounded, the Requeté carries him on his shoulders and, probably because of this act, a bullet also hits him.

The camaraderie Eugenio and the Falangist experience becomes a substitute for their families. Eugenio rejects his relatives because they belong to the bourgeoisie and in his opinion, represent a part of society that only cares about comfort and pleasures. The Falangist does not have his family's support either: 'Yo no tengo a nadie' (Miquelarena 1938a: 6). It is possible that his relatives 
have died, but it seems more plausible that they rejected his decision to join the Falange. Most of the Falangists were young men from rich and bourgeois families who decided to rebel against their parents' values and ideas. Thus, fellow Falangists played the role of the family.

Physical and emotional proximity causes the emergence of affection among soldiers. Patricia Vettel-Becker thinks that camaraderie on the front allows men a certain liberation of their feminine side through the possibility of taking care of each other, something they cannot do in their civil lives (2002: 84). This idea does not contradict Klaus Theweleit's opinion that men embrace war to move away from the feminine (1989: 360). On the one hand, men may join the army to leave behind women's influence - what Theweleit calls 'the morass of femaleness' - but another reason may be men's wish to experience the release of their feminine side through the relationship with their comrades. In this sense, soldiers' fraternity at war can be interpreted according to Eve Kosofsky Sedgwick's belief that there is a continuum between homosocial relationships, that is, 'social bonds between persons of the same sex' (Sedgwick 1985: 1), and homosexual relationships, in which there exists sexual attraction between same-sex individuals. This does not mean that all male bonding implies a homosexual component; there is a spectrum of possibilities from mere friendship to actual sexual intercourse. In fact, in male-dominated kinship systems such as the army, patriarchy and homophobia are prevalent.

In the above texts, the main characters experience strong male bonding, which allows us to apply Sedgwick's theory. This analysis would reveal that behind the heteronormative and homophobic values of military masculinity, it is feasible to find homoerotic or homosexual relationships between soldiers. According to R. Claire Snyder, the fraternal bonding in military organizations entails a certain amount of homoeroticism, 'even if unrecognized or explicitly denied by participants and others' (Snyder 1999: 152). The motto 'Don't ask, don't tell' reflects the existence of homosexuals in the army and at the same time the official prohibition of homosexual conduct. Therefore, the army is based on a clear division between the homosocial and the homosexual, but in reality this separation is not as rigid as it is manifested.

In García Serrano's novel, Rafael's admiration of Eugenio includes homoerotic connotations. Rafael praises Eugenio's behaviour and physical appearance frequently and thinks of him constantly. Moreover, the two friends are not opposed to physical affection; for example, when they meet in the summer, they hug each other closely. Once Eugenio is dead, Rafael feels that his friend is inside him, advising him how to act: 'no soy yo quien habla. Es Eugenio, siempre conmigo. Para siempre a mi lado. Me dice suave y las sílabas adquieren un prestigio violento' (1938: 104). This passage, besides bearing witness to the Falangist fraternity between living and dead soldiers, includes obvious homoerotic components.

Homoeroticism in the army can appear not only as a result of male bonding but also as a consequence of the loneliness soldiers have to endure. Paul Fussell 


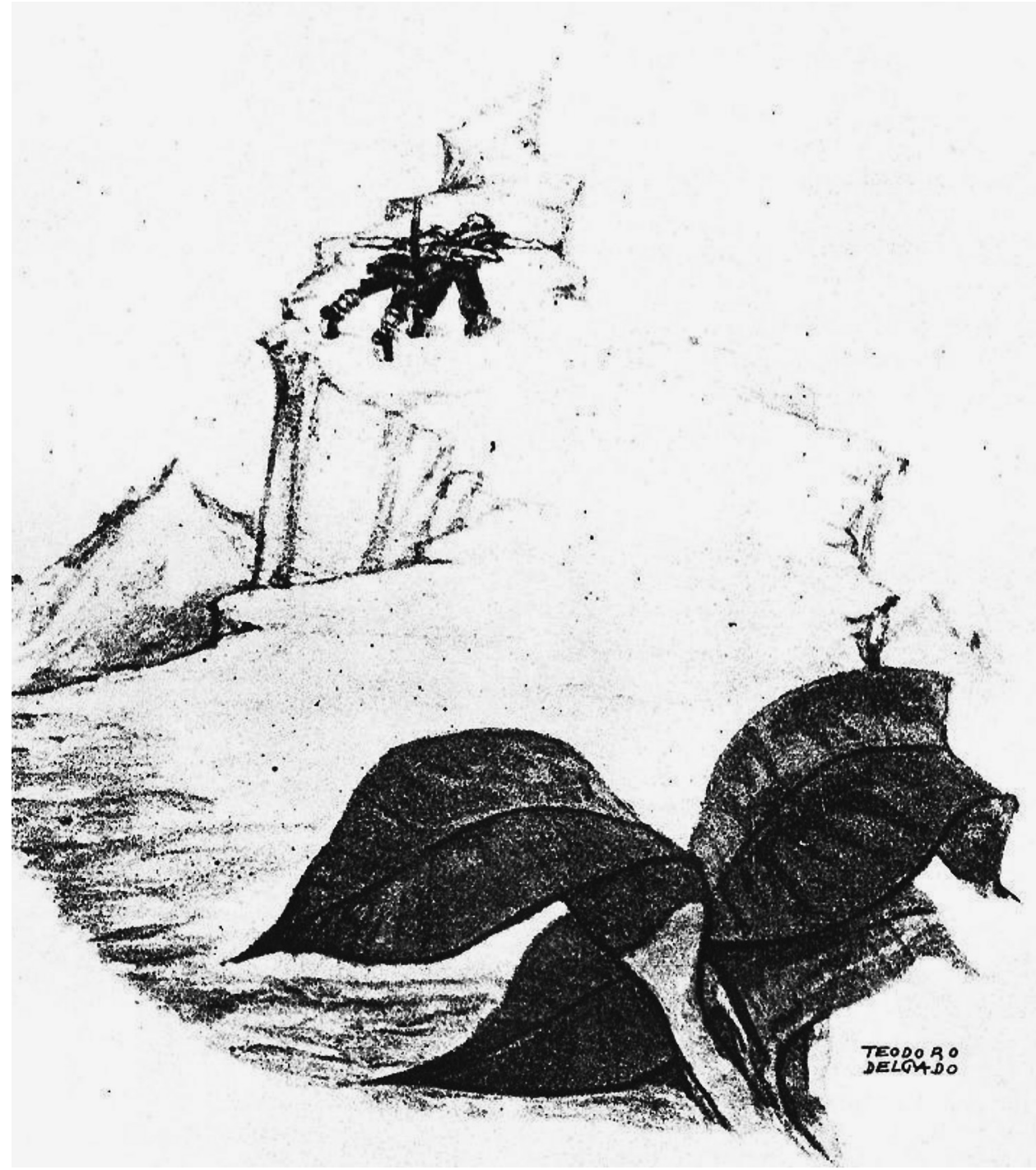

Fig. 3: Illustration by Teodoro Delgado in Unificación (1937), by Jacinto Miquelarena.

observes that soldiers' alienation on the front may cause the emergence of homoeroticism (1975: 272). This situation occurs in Unificación, where the isolation that the Falangist and the Requeté face together, as well as their mutual protection or 'manly nurturance', may allow for a homoerotic interpretation. In Miquelarena's work, the difference in age between the two characters makes their relationship similar to that of a master and an apprentice, alluding back to ancient Greek male liaisons. It is especially in their death together that homoeroticism appears more clearly. The narrator describes the situation as an embrace: 'El primer albor de la mañana, hecho todo él de nácar, encuentra dos cadáveres 
abrazados' (1938a: 11). This embrace, which the author uses to demonstrate the unity between Falangists and Carlists for the Francoist cause, resembles the way lovers die in romantic works. This relationship is also evident in the image that represents the protagonists' death, where the two corpses lie next to each other, one of them with his arm over the other (Fig. 3).

The physical proximity and affection between the characters in these two works may be interpreted as an expression of the Mediterranean masculinities, in contrast to the Anglo-American paradigm. Anthropologists and historians such as Robert Aldrich propose that in Mediterranean countries men enjoy a more flexible sexuality, in which the acts of holding hands and kissing each other on the cheek are acceptable behaviours. These activities may be explained by the fact that in Mediterranean cultures men occupy the public sphere while women are secluded, confined to the private. Furthermore, women are repeatedly portrayed as a 'threat, a symbol of disorder and chaos' (Gilmore 1982: 195). ${ }^{11}$ According to this model, southern European males are also more willing to engage in homosexual acts, during part of their lives at least, maintaining their social status as heterosexual men if they play the 'active' role in intercourse (Aldrich 1993: 176). In this way, sexual practices do not determine personal identity in the traditional sense of the word. As Alberto Mira states, the price of the Mediterranean paradigm is silence, since homosexual encounters cannot be discussed (2000: 245).

Besides geographical and cultural contexts, the homoerotic undertone present in these Falangist works can arise from their fascist ideology. Andrew Hewitt (1996) points out how opponents of fascism have linked fascist movements with homosexuality. Mosse attributes this connection to fascism's preoccupation with images of manliness (1999: 176). Even in the 1930s the enemies of fascism used to claim that the veneration of the Führer concealed homosexuality. Hewitt believes that the connection between fascism and homosexuality is not accidental, since both are considered dangerous and not conducive to liberal historical progress: 'The linkage of homosexuality and fascism results from the parallel fears that all social order might result in fascism, and that all homosocial structures are potentially homosexual' (1996: 11). Although this argument may be true, in all male groups in which the members live together, there is a continuum between homosociality and homosexuality.

The Falangist characters' rejection of romantic relationships with women supports the idea of homoeroticism. Thus, even though Eugenio starts dating María Victoria, he later decides to terminate the relationship with her because love for a woman interferes with his devotion to politics. He thinks that to fall in love is a bourgeois weakness; instead, the nation becomes for him a substitute for a girlfriend. The transformation of the nation into the soldier's girlfriend stems from the Francoist belief that the ability to control one's sexual urges

11 David Gilmore indicates that the ideal manliness in the Mediterranean consists of three moral imperatives: first, impregnating one's wife; second, provisioning dependents; third, protecting the family (1990: 48). 


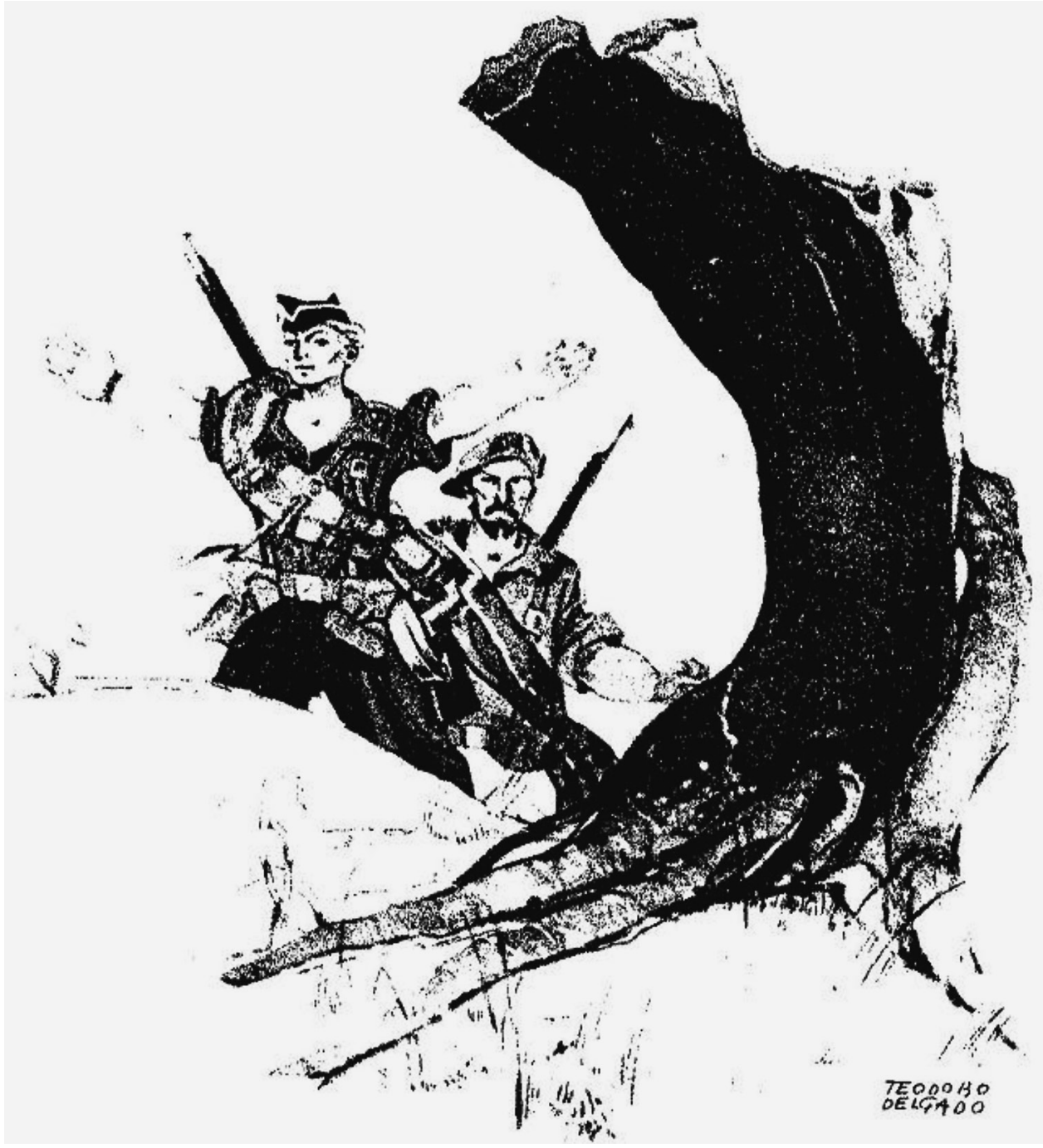

Fig. 4: Illustration by Teodoro Delgado in Unificación (1937),

by Jacinto Miquelarena.

is a sign of mental strength. In this way, Eugenio behaves like the figure of a warrior-saint such as Ignacio de Loyola, whose writings he reads and admires. In contrast, Rafael does not renounce love: he thinks of his girlfriend, Laura, and writes poems about her. However, he is allowed to do this because he is not fighting with arms for the nation's sake.

In Unificación, the Falangist also represents the model of the chaste soldier because of his youth. He has probably never had a girlfriend, which is revealed in the lyrics he sings: '¡Qué bien se va a la guerra, / qué bien se va! / Sin tener madre ni novia, / ¡qué bien se va!' (Miquelarena 1938a: 6). Without involvement in romantic relationships, Eugenio and the Falangist are free to devote themselves 
completely to the war. The Falangist even seems to experience the battle as a sexual act. He offers his body to the enemies as if he were abandoning himself in a masochistic way: ‘Qué bala enemiga quiere el pecho más joven de la Falange? [...] ¿Quién lo quiere? ¿Quién lo desea?’ (8). This sexual interpretation would contradict the military masculinity based on stoicism and the absence of individual pleasure. Following Lacan's theories, Adam Farrar believes that at war, the soldier enjoys the most intense jouissance (1985: 66). Mosse also states the connection between war and sex: 'The feeling of ecstasy as the bayonet sank into the white flesh of a French or English soldier was likened to an orgasm' (1985: 124). According to this analogy, the rifle may symbolize an extension of the soldier's penis, that is, a phallic instrument to conquer and possess the other. In this case, the Falangist's desire to be injured by the enemy's bullets could be read as his wish to be penetrated.

One of the illustrations of the book supports the interpretation of the battle as a sexual act (Fig. 4). In the picture, Delgado represents the Falangist walking in front of the Requeté, opening his arms as a Christ figure and offering his chest to the enemy bullets in a masochistic and suicidal way. The position of the Falangist is slightly reminiscent of that of the main character in the painting Los fusilamientos del tres de mayo (1814), by Francisco de Goya, an artist to whom both Republicans and rebels wanted to relate during the war. ${ }^{12}$ On the right side of Delgado's image there is a tree trunk that symbolizes the Falangist. The tree trunk has no branches or leaves; that is, it is close to death, but its roots are strongly anchored into the ground, meaning that its life will continue. In a similar way, the soldier is about to die, but his life will have had meaning because his spirit is indissolubly linked to the nation's earth and will stay alive in his fellow soldiers.

In Eugenio and Unificación, the characters show their love for the nation through the special connection they maintain with nature. Nature symbolizes the eternal, unchangeable essence of the nation, as opposed to industrialization and modernity. Falangists praised the country and especially Castille as the origin of the Spanish empire. José Antonio Primo de Rivera expressed the idea this way: 'Tenemos mucho que aprender de esta tierra y de este cielo de Castilla [...]; la tierra como depositaria de valores eternos, la austeridad en la conducta, el sentido religioso en la vida, el habla y el silencio, la solidaridad entre los antepasados y los descendientes' (1945: 27). In a 1938 article in Arriba España, García Serrano also idealized rural Spain: 'Queremos para después de la guerra una España campesina [...]’ (Díaz-Plaja 1979: 176).

In Eugenio, the protagonist rejects the city because it represents capitalism, liberalism and pacifism. In contrast, he considers nature the space where the essence of the nation lies. This is why he falls in love with María Victoria, who coist rebels tried to appropriate Goya's paintings about the Independence War as symbols of their fight. 
symbolically is from Castille. In Unificación, there are several illustrations representing peasants in an idyllic and rural environment. In one of them, arrows - which along with the yoke are the symbol of the Falange - sprout from the earth while a peasant gives the fascist salute. With this image, the Falangist ideology is connected to the Spanish earth and thus is naturalized. However, in Miquelarena's text, the mountain is the natural element that plays the most important role because it is the location of the main characters' death. In George Mosse's opinion, mountains have long symbolized the nation (1990: 114). Furthermore, the mountain may be identified with the soldier because both of them are strong and powerful. The soldier's arrival on the summit of the mountain exemplifies the physical effort he has made for his nation and stands for the conquest of eternal spaces. At the same time, it resembles the path that Christ followed on his way to death. This appears clearly in one of Teodoro Delgado's illustrations, where behind the Requeté, who carries the Falangist on his shoulder, a large cross connects both characters with Christ and assures their salvation (Fig. 5). At the same time, the mountainous landscape in the background represents the nation for which they are fighting and dying.

Death is the highest sacrifice a soldier can offer the nation. Ross Poole states that national ideologies have a more urgent need for men ready to die than for men determined to kill (1985: 77). Nationalism idealizes death as the culminating moment of an empty life. Theodor Körner's motto applies easily to the cases discussed here: 'Happiness lies only in sacrificial death' (Mosse 1990: 70). In their pursuit of fulfilment, the Falangist characters are willing to die for their nation. Gareth Thomas considers that in the Falangist novels, the desire for self-immolation in defence of the fatherland is due to the Catholic ascetic tradition of self-abnegation, although this critic also finds important influences of Nietzsche's theories of a super-race or 'select minority' in the generation of Falangist heroes (1990: 70-72).

In Eugenio, death is present from the novel's dedication to dead comrades and the title of the first chapter: 'Eugenio elige su muerte'. At the beginning, Eugenio establishes a classification of different types of death: circumstantial, bourgeois, forced, and desired. He chooses the last one because it is beautiful: 'mueres en combate y tu sangre se hace fértil como una primavera' (García Serrano 1938: 22). Eugenio thinks that to fight for the nation inevitably means to die: ' $Y$ es necesario que vayamos aprendiendo a morir porque ya es llegado el tiempo de la sangre en el campo' (40). The good Falangist must be able to sacrifice his life because his blood will join the nation's earth and bear fruit in the future. Jacinto Miquelarena stated that the Falangist does not care about dying: 'Piensa en la muerte alegremente, porque el falangista no muere nunca' (1938b: 126). In a 1936 article in Arriba España, García Serrano expressed the same idea: 'Morir es fácil, desde el primer día en la Falange’ (Díaz-Plaja 1979: 632). For this reason, Pedro Carlos González Cuevas calls the Falangist, in a Heideggerian way, 'un ser-parala-muerte' (2000: 129).

The promise of Eugenio's death is fulfilled at the end of García Serrano's 


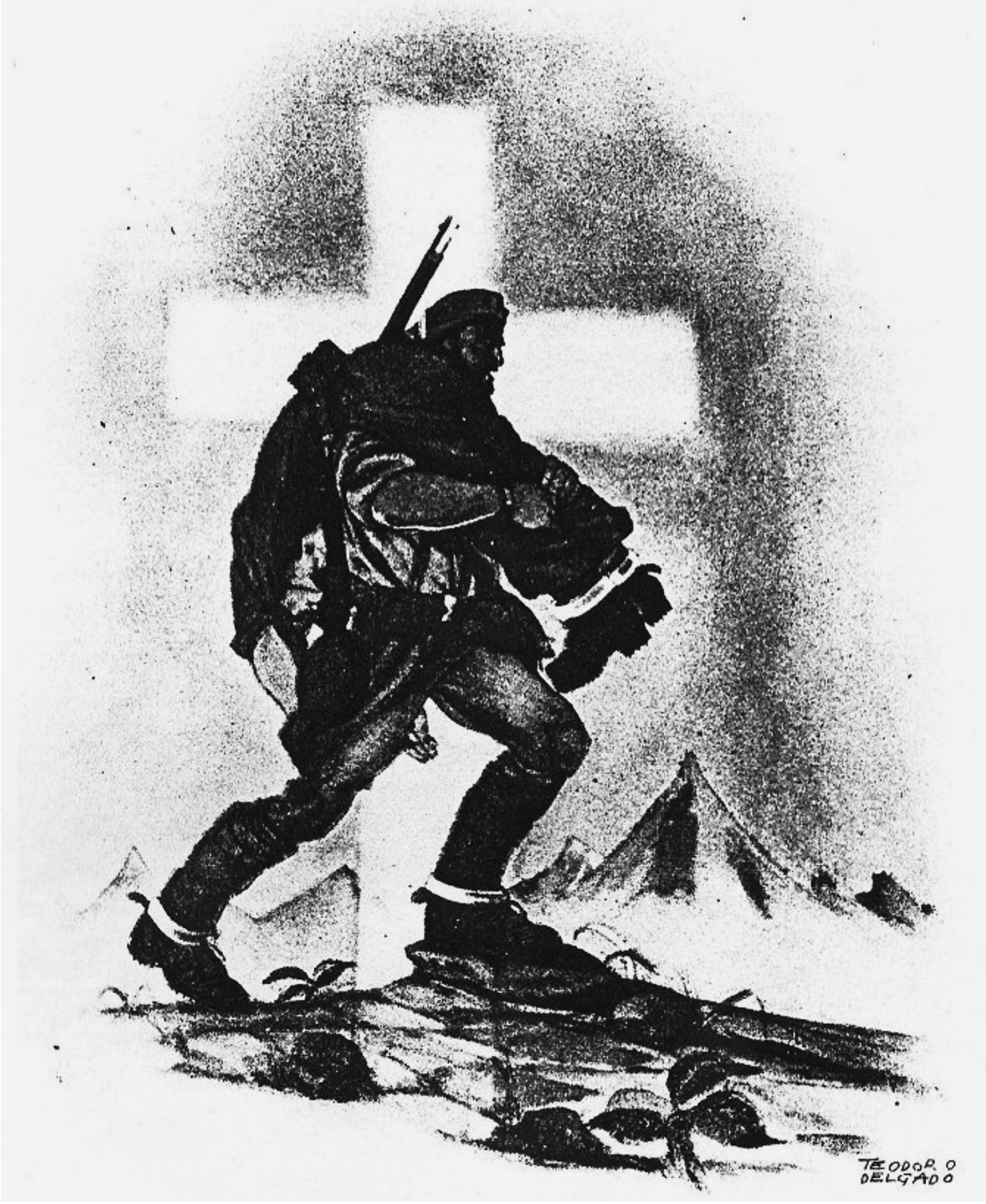

Fig. 5: Illustration by Teodoro Delgado in Unificación (1937), by Jacinto Miquelarena.

novel, in the chapter purposefully entitled 'Proclamación de la Primavera'. Spring here refers to the soldier's self-willed death, which will enable a new future for the nation. ${ }^{13}$ In one of the illustrations included in the novel, José

13 In addition to the metaphor of spring, the Falange also used the image of dawn to symbolize the resurgence of the new nation, for example in its hymn 'Cara al sol': '[...] Formaré junto a mis compañeros / que hacen guardia sobre los luceros / [...] ¡Arriba, escuadras, a vencer, / que en España empieza a amanecer!'. 


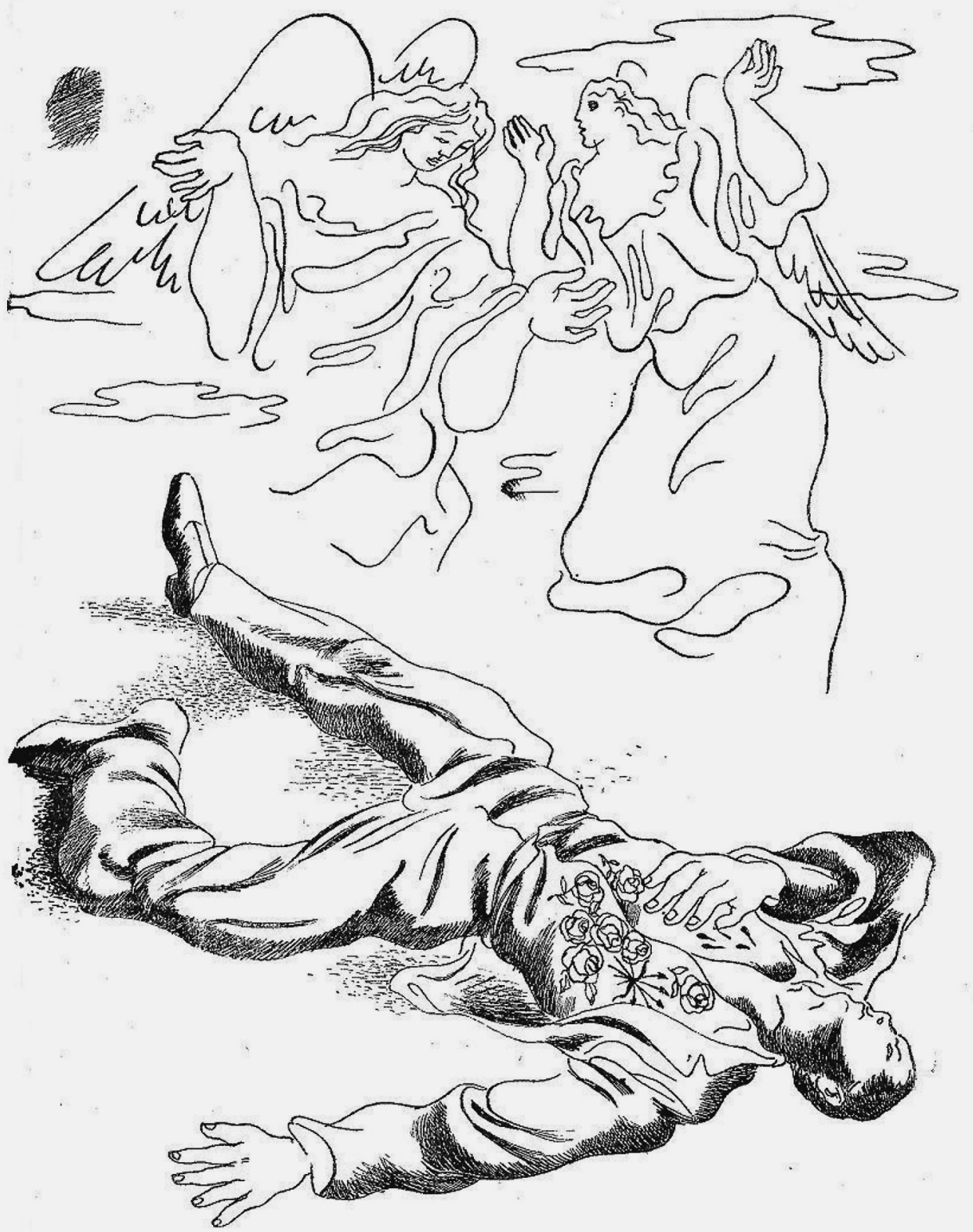

Fig. 6: Illustration by José Caballero in Eugenio (1938), by Rafael García Serrano.

Caballero represents Eugenio's death (Fig. 6). The guardian angels along the top of the image symbolize the salvation of the protagonist's soul. The angels appear because of the rebels' vision of the war as a crusade, an idea that helped them fight without fearing death. The angels' gestures show that Eugenio's death was unavoidable. On Eugenio's chest there are a few drops of blood, but also seven roses around the yoke and arrows, the emblem of the Falange. The roses indicate 
that Eugenio's blood has germinated and that his soul will stay alive. His blood will make the land fertile, in this way creating new heroes. The main character fulfils his mission to die: 'Eugenio sonrió al pensar en su vida; él nació para morir precisamente bajo el sol temprano de mayo’ (García Serrano 1938: 100).

In Unificación, as has been mentioned earlier, the Falangist also seeks death by offering his chest to enemy bullets. In Delgado's illustration representing the Falangist and the Requeté's death, the corpses are located on an ascendant mountainous path that signifies the salvation of their souls and their journey to heaven (Fig. 3). The plant drawn in the foreground also symbolizes life after death. Although both soldiers die, their sacrifice allows the nation to stay alive. Like the plant, they become part of the nation's soil and landscape. Christ's help and the soldiers' salvation after death are reiterative topics in Falangist and Francoist narratives, but they are not exclusive to this side of the war, since in some Republican works written during the conflict, dead soldiers are also portrayed as martyrs. $^{14}$

Although the protagonists' death at the end of the narratives could be interpreted as pessimistic, in order for a soldier to be remembered, his glorious death is more important than his victory in a battle. In this way, the soldier's demise is a necessary step to reach immortality. The characters die as a consequence of their courage and their death is an example of martyrdom because they accept it silently, without complaints or curses. The protagonists prove that they are, in fact, heroes at the moment of their death. As Drew Gilpin Faust points out in her analysis of the American Civil War, the way a soldier dies during war predicts the quality of his everlasting life (2001: 10). García Serrano and Miquelarena narrate their characters' death in detail because the dead soldier becomes the driving force for his fellow living soldiers. As Mosse explains, dead soldiers create a national fraternity that joins heaven, life and death (1990: 79). In fact, the dead soldier does not count as an individual, but as a member of a confraternity. Eugenio clearly expresses the difference between the Falangist and Republican dead: 'Sus muertos se quedaban solos. Y los nuestros no. Forman guardia. Siguen en la hermandad caliente de cada corazón' (García Serrano 1938: 63). Falangists created a strong concept of fraternity between dead and living soldiers. For instance, in meetings, they used to remember deceased soldiers by referring to them as 'Present!' to acknowledge their everlasting active role in the fight. They even read a prayer at funerals, 'Oración a los caídos por la revolución nacional española', in which the dead Falangists were considered martyrs of the new Spain: 'Haz que la sangre de los muertos, Señor, sea el brote primero de la redención de esta España’ (Doctrina 1939: 9).

During the Spanish Civil War, the Falange emphasized violence and selfsacrifice as core characteristics of their male members. A fit and healthy body through the practice of sports was also considered essential, since it represented

14 Patricia Greene also finds religious iconography in several Republican war posters (1998: 121). An explanation for this use may be that religious symbols are appealing and suggestive to the masses. 
the nation's strength and possibilities of future achievements. The glorification of youth appears clearly in the two texts I have analysed; because of their energy and high ideals, the young Falangists are the ones in charge of constructing a new Spain and recovering its imperial past. Eugenio and the Falangist experience the war as a necessary rite of passage into manhood. They are pressured to demonstrate that they are not cowards and are ready to offer their lives for the nation. At the same time, they renounce romantic relationships because the nation takes on a gendered role: it symbolizes the girlfriend they must save. The protagonists also foster their patriotism through camaraderie, establishing a close bond with one another. Their fellow soldiers replace the bourgeois families they reject and allow them to feel like members of the national community. Thus, the nation is conceived as a men's fraternity. For the main characters, the essence of the nation lies in natural spaces, away from civilization and urban areas. In fact, when the protagonists die, their blood becomes part of the national landscape. Eugenio and the Falangist's willingness to die illustrates the Falange's conviction in the reward of salvation after death and in the soldiers' immortality, as their memory persists in their fellow comrades. In this way, the dead soldiers are identified with martyrs: like Christ, they are believed to have died for the salvation of humanity and they will always be remembered.

In the two texts discussed in this essay, the characters are idealized as perfect citizen soldiers, following the models of the chaste soldier or warrior-saint. Unlike some Republican works in which there is a realistic depiction of the soldier's daily life, García Serrano and Miquelarena construct characters that do not show doubts, curse, or make sexual references. Nevertheless, these works display certain aspects that fall into contradiction with the heteronormative and stoic model of military masculinity proposed by national ideologies. Fraternity on the front may transform into homoerotic relationships, while in Unificación, the model of the chaste and pure soldier does not seem compatible with the experience of fighting as a sexual act, almost orgasmic. These examples reveal that there is not simply one homogeneous military masculinity, as is suggested by national ideologies, but multiple military masculinities.

Eugenio and Unificación are two propagandistic works that convey the idea of the necessity of sacrifice at times of conflict. During the Spanish Civil War, these texts probably comforted the families of dead soldiers and clearly encouraged young men to join the Falange in order to fight until death. At the same time, García Serrano and Miquelarena emphasized the importance of the specific values of the Falange, so their works might be understood as a public recognition of this political party during the Spanish Civil War. Although Miquelarena's text presents the unification between Falangists and Carlists in a positive light, it is ironic that the Falangist and the Requeté's deaths would later come to symbolize the progressive ideological disappearance of the Falange and Carlism under Franco's government. 


\section{Works Cited}

Aldrich, Robert, 1993. The Seduction of the Mediterranean: Writing, Art and Homosexual Fantasy (London: Routledge).

Anderson, Benedict, 1991. Imagined Communities: Reflections on the Origin and Spread of Nationalism (London: Verso).

Braudy, Leo, 2003. From Chivalry to Terrorism: War and the Changing Nature of Masculinity (New York: Alfred A. Knopf).

Canal, Jordi, 2000. 'La violencia carlista tras el tiempo de las carlistadas: nuevas formas para un viejo movimiento', in Santos Juliá (ed.), Violencia política en la España del siglo XX (Madrid: Taurus), pp. 25-66.

Carbajosa, Mónica, and Pablo Carbajosa, 2003. La corte literaria de José Antonio: La primera generación cultural de la Falange (Barcelona: Crítica).

Connell, R. W., 2000. The Men and the Boys (Berkeley, CA: University of California Press).

-, 2001. 'Studying Men and Masculinity', Resources for Feminist Research, 29.2: 43-55.

Dawson, Graham, 1994. Soldier Heroes: British Adventure, Empire and the Imagining of Masculinities (London: Routledge).

Díaz-Plaja, Fernando, 1979. Si mi pluma valiera tu pistola: Los escritores españoles en la guerra civil (Barcelona: Plaza y Janés).

Doctrina e historia de la revolución nacional española, 1939 (Barcelona: Agustín Núñez).

Eisenstein, Zillah, 2000. 'Writing Bodies on the Nation for the Globe', in Sita Ranchod-Nilsson and Mary Ann Tétreault (eds), Women, States and Nationalisms: At Home in the Nation? (London: Routledge), pp. 35-53.

Farrar, Adam, 1985. 'War: Machining Male Desire', in Paul Patton and Ross Poole (eds), War / Masculinity (Sydney: Intervention Publications), pp. 59-70.

Faust, Drew Gilpin, 2001. 'The Civil War Soldier and the Art of Dying', The Journal of Southern History, 67.1: 3-38.

Fussell, Paul, 1975. The Great War and Modern Memory (New York: Oxford University Press).

-, 1989. Wartime: Understanding and Behavior in the Second World War (New York: Oxford University Press).

García-Posada, Miguel, 1998. 'Un andaluz profundo', in José Caballero, El tiempo de un poeta (Madrid: Consejería de Educación y Cultura), pp. 17-33.

García Serrano, Rafael, 1938. Eugenio o proclamación de la Primavera (Bilbao: Jerarquía).

Gilmore, David D., 1982. 'Anthropology of the Mediterranean Area', Annual Review of Anthropology, 11: 175-205.

-, 1990. Manhood in the Making: Cultural Concepts of Masculinity (New Haven, CT: Yale University Press).

González-Allende, Iker, 2004. 'Eugenio o proclamación de la Primavera, de García Serrano: Narrativa falangista durante la guerra civil', Letras de Deusto, 34.102: 77-99.

González Cuevas, Pedro Carlos, 2000. 'Política de lo sublime y teología de la violencia en la derecha española', in Santos Juliá (ed.), Violencia política en la España del siglo XX (Madrid: Taurus), pp. 105-43.

Greene, Patricia V., 1998. 'Testimonio visual: Iconografía femenina en los carteles en la Guerra Civil', Letras Peninsulares, 11.1: 119-43.

Harrison, Deborah, 2003. 'Violence in the Military Community', in Paul R. Higate (ed.), Military Masculinities: Identity and the State (Westport, CT: Praeger), pp. 71-90.

Hewitt, Andrew, 1996. Political Inversions: Homosexuality, Fascism, and the Modernist Imaginary (Stanford, CA: Stanford University Press).

Llorente, Ángel, 1995. Arte e ideología en el franquismo (1936-1951) (Madrid: Visor).

MacClancy, Jeremy, 2000. The Decline of Carlism (Reno, NV: University of Nevada Press).

Mainer, José-Carlos, 2001. 'Sobre la imagen del fascismo en la novela española de la primera postguerra', in Paul Aubert (ed.), La novela en España (siglos XIX-XX) (Madrid: Casa de Velázquez), pp. 175-92.

Miquelarena Regueiro, Jacinto, 1938a [1937]. Unificación (Tolosa: Gráficas Laborde y Labayen).

-, 1938b. El otro mundo: La vida en las embajadas de Madrid (Burgos: Aldecoa). 
Mira, Alberto, 2000. 'Laws of Silence: Homosexual Identity and Visibility in Contemporary Spanish Culture', in Barry Jordan and Rikki Morgan-Tamosunas (eds), Contemporary Spanish Cultural Studies (London: Arnold), pp. 241-50.

Mosse, George L., 1985. Nationalism and Sexuality: Respectability and Abnormal Sexuality in Modern Europe (New York: H. Fertig).

-, 1990. Fallen Soldiers: Reshaping the Memory of the World Wars (New York: Oxford University Press).

-, 1996. The Image of Man: The Creation of Modern Masculinity (New York: Oxford University Press).

-, 1999. The Fascist Revolution: Toward a General Theory of Fascism (New York: Howard Fertig).

Payne, Stanley G., 1961. Falange: A History of Spanish Fascism (Stanford, CA: Stanford University Press).

-, 2003. 'Fascism as a Generic Concept', in Aristotle A. Kallis (ed.), The Fascism Reader (London: Routledge), pp. 82-88.

Poole, Ross, 1985. 'Structures of Identity: Gender and Nationalism', in Paul Patton and Ross Poole (eds), War / Masculinity (Sydney: Intervention Publications), pp. 71-79.

Primo de Rivera, José Antonio, 1945. Obras completas (Madrid: FET y de las JONS).

Rodríguez-Puértolas, Julio, 1986. Literatura fascista española: Historia (Madrid: Akal).

Sedgwick, Eve Kosofsky, 1985. Between Men: English Literature and Male Homosocial Desire (New York: Columbia University Press).

Snyder, R. Claire, 1999. Citizen-Soldiers and Manly Warriors: Military Service and Gender in the Civic Republic Tradition (Lanham, MD: Rowman \& Littlefield).

Theweleit, Klaus, 1989. Male Fantasies: Male Bodies, Psychoanalyzing the White Terror. Trans. Stephen Conway, Erica Carter and Chris Turner (Minneapolis, MN: University of Minnesota Press).

Thomas, Gareth, 1990. The Novel of the Spanish Civil War (1936-1975) (Cambridge: Cambridge University Press).

Trapiello, Andrés, 1994. Las armas y las letras: Literatura y guerra civil (1936-1939) (Barcelona: Planeta).

Vettel-Becker, Patricia, 2002. 'Destruction and Delight: World War II Combat Photography and the Aesthetic Inscription of Masculine Identity', Men and Masculinities, 5.1: 80-102.

Wakefield, Wanda Ellen, 1997. Playing to Win: Sports and the American Military, 1898-1945 (Albany, NY: State University of New York Press).

Woodward, Rachel, 2003. 'Locating Military Masculinities: Space, Place, and the Formation of Gender Identity in the British Army', in Paul R. Higate (ed.), Military Masculinities: Identity and the State (Westport, CT: Praeger), pp. 43-55. 